\title{
Comparison of broiler performance using Plantain (Plantago lanceolata L.), Bio-Sel-E and commercial diet
}

\author{
R Chacrabati ${ }^{1}$, R Chowdhury ${ }^{1}$, S Yesmin $^{1}$, H Sano ${ }^{2}$, M Al-Mamun* ${ }^{1}$ \\ ${ }^{1}$ Department of Animal Nutrition, Bangladesh Agricultural University, Mymensingh 2202, Bangladesh; \\ ${ }^{2}$ Department of Animal Sciences, I wate University, Morioka 020-8550, Japan
}

\begin{abstract}
An experiment was conducted to determine the impact of Plantain (PL), Bio-Sel-E and commercial broiler diet on the growth performance, feed conversion ratio, performance index and carcass yield of broiler. A total of 160 day old broiler chicks (Cobb-500) were randomly distributed into four groups with four replication in each group and having 10 birds in each replication. Basal diet was used for group 1 (control), Basal diet was supplemented with PL $(0.5 \%$ of DM basis) and Bio-Sel-E (5g/50 birds in drinking water) for group 2 and 3 respectively and for group 4 used commercial broiler diet (Quality Feed Ltd.). Total feed intake was similar among the groups. Feed conversion ratios of PL diet, Bio-Sel-E diet, and commercial broiler diet were comparable, and were lower $(P<0.05)$ than the control diet. Significantly higher body weight gain and performance index were found in PL, Bio-Sel-E and commercial broiler diet groups than control diet. The dressing yield of PL diet and commercial broiler diet were comparable, and they were higher $(\mathrm{P}<0.05)$ than Control diet and Bio-Sel-E diet. It could be concluded that the Supplementation of $0.5 \% \mathrm{PL}$ in the diet had positive effect on growth, feed intake, feed conversion ratio, performance index and carcass characteristics of broilers almost similar of Bio-Sel-E and commercial broiler diet.
\end{abstract}

Key words: Broiler, Plantain, Bio-Sel-E, Commercial diet, Performance.

Bangladesh Animal Husbandry Association. All rights reserved. Bang. J. Anim. Sci. 2013. 42 (2): 123-130

\section{I ntroduction}

Commercial broiler production has become a specialized and speedy poultry operation during the recent years all over the world. Now a days, this industry has focused more attention towards addressing public concern for environmental and food safety. The demand of livestock products throughout the world is increasing concurrently with the increase of population. The use of synthetic antibiotic growth promoters in animal feeding was a common practice more than four decades (Wegener et al. 1999), but the use of antibiotic growth promoters has been prohibited in the European Union (EU) since 2006. Because of side effects and hazardous effects of antibiotics and chemical compounds for poultry health and its residues in meat can make danger for human health, consumers prefers organic meat without chemical or antibiotic residues (Aritajat et al. 2008). People are giving more attention towards the quality of foodstuffs. Natural antioxidants can protect the biologically important cellular components from oxidative processes caused by reactive oxygen species (Su et al. 2007). Herbs and organic acid have received an increased attention as an alternative to antibiotics (Ricke, 2003). Various herbal products are being used as growth promoters in the poultry rations like garlic (Ahmad, 2005) and kalongi (Ihsan, 2003). Plantain (Plantago lanceolata L.) (PL) is one of the perennial herbs having some bioactive compounds such as acteoside, aucubin, and catalpol (Nishibe and Murai, 1995), which have anti-oxidative activity (Wang et al. 1996) and anti-inflammatory effects (Marchesan et al. 1998). Feeding poultry a higher level of natural dietary antioxidants provides the poultry industry with a simple method for improving oxidative stability, sensory quality, shelf life, and acceptability of poultry meats (Buckley and Morrissey 1992). Plantain has been used in herbal medicine in Europe (Nishibe and Murai 1995), and is currently being evaluated in New Zealand as a potential pasture species because of its medicinal value to animals (Deaker et al. 1994). Plantain is important from the animal feeding point of view because of its medicinal value to animals, improving their physiological conditions and diminishing the need for antibiotic growth 


\section{Broiler performance using Plantain, Bio-Sel- E and commercial diet}

promoters. Moreover, Plantain is not only a source of bioactive components but also a good source of protein and minerals (Al-Mamun et al. 2008). Plantain was reported to contain tannins, thus they, too, might affect carcass composition (Dorfler and Roselt 1989).

Bio-Sel-E contains biotin, vitamin E and selenium. Selenium is an essential trace mineral in poultry for body development and maintenance of glutathione peroxidase activity (Whitracre et al. 1986). Selenium has important health promoting effect as it is one of the most active natural antioxidants; when combined with vitamin $E$, it may enhance the immune function ( $L u$ et al., 2005). Vitamin $E$ is the most active antioxidant used in animal or bird feeding (Flachowsky 2002). So Bio-Sel-E is also important for broiler production.

In Bangladesh Poultry feed producers haphazardly use sub-therapeutic level of Antibiotic Growth Promoters (AGPs) in feed without concerning their negative impact on human health. So the hazardous effect of antibiotics adversely acts on the health of consumers. In light of this situation PL and BioSel-E can be considered as the effective alternative to antibiotic growth promoters in broiler production. Considering the above statements the present research work was designed to study the effect of PL and Bio-Sel-E on the growth performance, feed consumption, feed conversion ratio and carcass characteristics of broiler and to compare the performance of broiler fed PL, Bio-Sel-E and commercial broiler diet.

\section{Materials and Methods}

The experiment was conducted in the poultry rearing unit at the Shahjalal Animal Nutrition Field Laboratory, Bangladesh Agricultural University, Mymensingh for a period of 35 days (from $7^{\text {th }}$ March to $10^{\text {th }}$ April).

One hundred and sixty straight run day-old broiler chicks (Cobb-500) were purchased from a commercial hatchery. Plantain (PL) was cultivated at the Shahjalal Animal Nutrition Field. Bio-Sel-E was purchased from Avon Animal Health Limited and commercial broiler feed (Quality Feed Ltd.) were purchased from local shop. Fresh PL was cut from the land and chopping into small pieces. Chopped PL mixed with control diet and supplied to the birds. Bio-Sel-E was supplied with drinking water. The experiment was conducted in a completely randomized design (CRD). The chicks were randomly divided into 4 equal groups with 4 replicates in cages each having 10 chicks.

Feed ingredients (maize, soybean meal, rice polish) were finely ground individually using a grinding machine. After weighing required amount of ground maize and soybean meal were hand mixed thoroughly. Soybean oil $(0.5 \mathrm{~kg} / 100$ $\mathrm{kg}$ feed) was mixed with the mixture of maize and soybean meal. Protein concentrate, Common Salt, Di-Calcium Phosphate, limestone, Vitamin-Mineral Premix, Methionine, Lysine were mixed homogenously with the whole feed. It was done by mixing all these premix first with a small quantity of mixed feed and then with gradual increase in quantity by adding remaining mixed feed. Finally, total amount of feed was mixed thoroughly. The mixed feed was then divided into 3 equal parts for 3 groups. The chemical composition of formulated diet was almost similar with commercial diet. The chemical composition of Plantain, ingredients amount and chemical composition of the experimental diet and commercial broiler diets is shown in Table 1, 2 and 3 , respectively.

Table 1. Chemical composition of Plantain

\begin{tabular}{ll}
\hline Components & $\begin{array}{l}\text { Amount } \\
(\%)\end{array}$ \\
\hline Dry matter (DM) & 13.00 \\
Crude protein(CP) & 9.31 \\
Crude fibre (CF) & 13.25 \\
Ether extract (EE) & 3.10 \\
Ash & 7.39 \\
Calcium (Ca) & 1.70 \\
Phosphorus ( P) & 0.29 \\
Acteoside & 1.06 \\
Aucubin & 0.65 \\
Catalpol & 0.0004 \\
\hline
\end{tabular}

Source: Bioactive components and production performances of Ecotypes of plantain (Plantago lanceolata L.) herb in northern Japan, Dr. Mohammad Al-Mamun 2008)

The experimental house contained 16 cages each had a floor space of $0.91 \mathrm{~m}^{2}(120 \mathrm{~cm} \times 76 \mathrm{~cm})$ among those 16 cages were considered for this trial. The experimental house (ceiling, wall, floor 
and wire net) were properly brushed and washed by forced water, then floor of the house was disinfected by using phenyl solution and the room was left vacant for 7 days. At the same time, all feeders, plastic buckets, waterers and other necessary equipments were also properly cleaned, washed and disinfected with bleaching powder solution. After arrival of chicks in the experimental house, they were supplied $5 \%$ glucose solution to minimize stress for transportation. The chicks were distributed randomly to individual cage one day after arrival according to treatment where one round feeder and one waterer were placed previously. Ten chicks were allocated in each cage. For light and temperature control, a 100 watt electric bulb was used for each cage. Lighting periods of 24 hours per day were provided throughout the experimental period. The brooding temperature was maintained at $34^{\circ} \mathrm{C}$ for the first week. In the course of the trial, the temperature was gradually reduced at the end of the trial. For optimum ventilation the windows and door were opened in the morning and closed in the evening. Feed in the form of mash was supplied to the chicks on clean newspaper for the first 3 days and water was supplied in round plastic drinkers from the first day. After 3 days of age, feed was supplied in round feeder. Feeds and water were offered two times (7.30/am and $4.00 / \mathrm{pm}$ ) daily on ad libitum basis to the experimental chicks. Sawdust was used as litter material at a depth of $4 \mathrm{~cm}$. Every two days interval litter was stirred to prevent ammonia gas and maggot formation. All the experimental chicks were vaccinated against Infectious Bursal Disease and New castle disease. Proper bio-security measures were taken during the experimental period. The following records were kept during five weeks of the experimental period.

Chicks were weighed in a group for each replication during onset of the trial and at the age of $7,14,21,28$ and 35 days. The average body weight gain of chicks in each replication was calculated by deducting initial body weight from the final body weight.
Feed intake, feed conversion efficiency and feed conversion ratio were calculated using following formula:

(a) Feed consumption ( $\mathrm{g} /$ chick) $=$

Feed consumed $(\mathrm{g})$

Number of chicks

(b) Feed conversion ratio $(F C R)=$

$\frac{\text { Feed intake }(\mathrm{g})}{\text { Weight gain }(\mathrm{g})}$

(c) \% Performance Index (PI) =

$\frac{\text { Body weight }(\mathrm{kg})}{\mathrm{FCR}} \times 100$ (Lanson

and Smyth 1955)

Table 2. Chemical composition of the Commercial broiler diet

\begin{tabular}{ll}
\hline Chemical constituents & Amount \\
\hline Dry matter (DM) & $89.00 \%$ \\
Crude protein (CP) & $23 \%$ \\
Crude fibre (CF) & $5.00 \%$ \\
Ether extract (EE) & $5.00 \%$ \\
NFE & $48.61 \%$ \\
Ash & $8.39 \%$ \\
Ca & $0.9 \%$ \\
P & $0.8 \%$ \\
$*$ ME (kcal/kg DM) & 3100.00 \\
\hline
\end{tabular}

${ }^{*}$ Chemical composition of formulated diet and commercial broiler diet was almost similar

At the end of the experimental period (35 days), one broiler from each replication was slaughtered for determining dressing yield. Broilers were selected based on mean weight of each replication. Broilers were identified using number on leg band and slaughtered by Halal method. After complete bleeding broilers were weighed, then skins were removed and pinning was done manually. Head and shank were separated; viscera and giblet (heart, liver, spleen, and gizzard) were removed from the carcass. Weight of skin, shank, head, viscera, giblet and carcass were taken individually and recorded.

Samples of supplied diet and samples of PL were analyzed in the laboratory and using SAS statistical program for one-way analysis of variance (ANOVA) (SAS 1996). 


\section{Broiler performance using Plantain, Bio- Sel- E and commercial diet}

Table 3. I ngredients amount and chemical composition of the experimental diet

\begin{tabular}{|c|c|c|c|}
\hline Ingredient & $\begin{array}{l}\text { Amount } \\
(\mathrm{kg} / 100 \mathrm{~kg})\end{array}$ & $\begin{array}{l}\text { Chemical } \\
\text { constituents }\end{array}$ & Amount \\
\hline Maize & 55.00 & Dry matter (DM) & $89.00 \%$ \\
\hline Soybean meal & 29.00 & Crude protein $(\mathrm{CP})$ & $23.00 \%$ \\
\hline Rice polish & 7.00 & Crude fibre(CF) & $5.00 \%$ \\
\hline Protein concentrate & 5.00 & Ether extract(EE) & $4.00 \%$ \\
\hline Soybean oil & 0.50 & NFE & $48.61 \%$ \\
\hline Salt & 0.40 & Ash & $8.39 \%$ \\
\hline Di-Calcium Phosphate & 2.00 & $\mathrm{Ca}$ & $0.84 \%$ \\
\hline Limestone & 0.50 & $P$ & $0.56 \%$ \\
\hline Vitamin-mineral premix ${ }^{a}$ & 0.25 & *ME (kcal/kg DM) & 3150.00 \\
\hline Lysine & 0.15 & & \\
\hline Methionine & 0.15 & & \\
\hline Choline chloride & 0.05 & & \\
\hline
\end{tabular}

* Calculated using the formula of Wiseman (1987) and followed recommendation of Cobb 500 broiler strain

Table 4. Body weight gain ( $\mathrm{g} / \mathrm{bird}$ ) of broilers under different dietary treatments

\begin{tabular}{|c|c|c|c|c|c|}
\hline \multirow[t]{2}{*}{ Age (week) } & \multicolumn{4}{|c|}{ Dietary treatment (Mean $\pm \mathrm{SE}$ ) } & \multirow[t]{2}{*}{ Sig. level } \\
\hline & Control & $\begin{array}{l}\text { Plantain }(0.5 \% \\
\text { of the diet) }\end{array}$ & Bio- Sel-E & $\begin{array}{l}\text { Commercial broiler diet } \\
\text { (Quality Feed Ltd.) }\end{array}$ & \\
\hline $1^{\mathrm{st}}$ & $86 \pm 0.75$ & $88 \pm 1.93$ & $88 \pm 3.42$ & $89 \pm 1.77$ & NS \\
\hline $2^{\text {nd }}$ & $123^{\mathrm{C}} \pm 2.86$ & $202^{a} \pm 1.60$ & $170^{\mathrm{b}} \pm 2.88$ & $203^{a} \pm 2.12$ & $* *$ \\
\hline $3^{\text {rd }}$ & $174^{\mathrm{C}} \pm 5.15$ & $229^{a} \pm 3.14$ & $205^{b} \pm 2.04$ & $230^{\mathrm{a}} \pm 2.79$ & $* *$ \\
\hline $4^{\text {th }}$ & $221^{\mathrm{b}} \pm 3.75$ & $250^{\mathrm{a}} \pm 2.88$ & $250^{\mathrm{a}} \pm 2.04$ & $248^{a} \pm 3.58$ & $* *$ \\
\hline $5^{\text {th }}$ & $293^{\mathrm{b}} \pm 4.78$ & $326^{\mathrm{ab}} \pm 12.47$ & $350^{\mathrm{a}} \pm 17.07$ & $327^{\mathrm{ab}} \pm 12.39$ & $*$ \\
\hline
\end{tabular}

Mean values with dissimilar superscripts in the same row differed significantly; SE, standard error; $*, \mathrm{P}<0.05$ $* *, \mathrm{P}<0.01$; NS, Non-significant $(\mathrm{P}>0.05)$

\section{Results}

Results on weekly body weight, body weight gain feed consumption, feed conversion ratio, performance index and carcass traits of broilers are presented in different subheadings.

The weight gain of broilers of different treatment groups and ages are shown in Table 4. There were insignificant differ in body weight gain among treatment groups during $1^{\text {st }}$ week of age but significant appears from $2^{\text {nd }}$ to $5^{\text {th }}$ weeks of age. At the end of the trail, birds fed Bio-Sel-E showed significantly higher weight gain compared to control whereas PL and commercial broiler diet fed birds showed insignificant differ compared to Bio-Sel-E and control.

The weekly feed intake of broilers in different groups is shown in Table 5 . Until $1^{\text {st }}$ week of age there was no significant difference among four treatment groups. Insignificant differ in feed intake was observed at $1^{\text {st }}, 4^{\text {th }}$ and $5^{\text {th }}$ weeks of age but during $2^{\text {nd }}$ and $3^{\text {rd }}$ weeks of age significant difference was recorded. The highest feed intake was found in Bio-Sel-E group followed by others at $5^{\text {th }}$ weeks of age. PL and commercial broiler diet fed group resulted significantly higher feed intake than control and Bio-Sel-E group at $2^{\text {th }}(P<0.01)$ and $3^{\text {rd }}(P<0.05)$ weeks of age.

The feed conversion ratio ( $g$ feed intake/g weight gain) of broilers receiving different dietary treatments is shown in Table 6. There were no significant differences on Feed Conversion Ratio among four treatments group until $3^{\text {rd }}$ weeks of age. On $4^{\text {th }}$ and $5^{\text {th }}$ weeks of age, PL, Bio-Sel-E and commercial broiler diet groups given insignificant result but significantly $(P<0.05)$ differed from control group. 
Chacrabati et al. (2013) Bang. J. Anim. Sci. 42 (2): 123- 130

Table 5. Feed intakes ( $\mathrm{g} /$ week) of broilers under different dietary treatments

\begin{tabular}{llllll}
\hline $\begin{array}{l}\text { Age } \\
(\text { wk })\end{array}$ & Control & $\begin{array}{l}\text { Plantain } \\
(0.5 \% \text { of the diet) }\end{array}$ & Bio- Sel-E & $\begin{array}{l}\text { Commercial diet } \\
\text { (Quality Feed Ltd. })\end{array}$ & $\begin{array}{c}\text { Sig. } \\
\text { level }\end{array}$ \\
\cline { 2 - 6 } & & $118 \pm 1.70$ & $117 \pm 4.56$ & $116 \pm 0.28$ & $\mathrm{NS}$ \\
\hline $1^{\text {st }}$ & $120 \pm 1.75$ & $291^{\mathrm{a}} \pm 8.22$ & $252^{\mathrm{b}} \pm 5.72$ & $290^{\mathrm{a}} \pm 7.68$ & $* *$ \\
$2^{\text {nd }}$ & $191^{\mathrm{c}} \pm 9.80$ & $369^{\mathrm{a}} \pm 20.13$ & $338^{\mathrm{ab}} \pm 8.44$ & $372^{\mathrm{a}} \pm 19.57$ & $*$ \\
$3^{\text {rd }}$ & $300^{\mathrm{b}} \pm 11.52$ & $477 \pm 11.54$ & $493 \pm 10.81$ & $480 \pm 11.44$ & $\mathrm{NS}$ \\
$4^{\text {th }}$ & $466 \pm 8.55$ & $663 \pm 30.45$ & $739 \pm 43.50$ & $691 \pm 14.67$ & $\mathrm{NS}$ \\
$5^{\text {th }}$ & $676 \pm 18.72$ & & & & $*$ \\
\hline
\end{tabular}

Mean values with dissimilar superscripts are in the same row differed significantly; SE, standard error; *, $\mathrm{P}<0.05 ; * *, \mathrm{P}<0.01 ; \mathrm{NS}$, Non-significant $(\mathrm{P}>0.05)$

The performance index (Body weight in $\mathrm{kg} / \mathrm{FCR}$ $\times 100$ ) of broilers in different groups is shown in Table 7. At the age of $1^{\text {st }}$ week of age there was no significant difference among four treatment groups whereas significant differ observed from $2^{\text {nd }}$ weeks of age. PL and commercial broiler diet fed groups resulted significantly $(P<0.01)$ higher performance index than control and Bio-Sel-E group at $2^{\text {th }} 3^{\text {rd }}$ and $4^{\text {th }}$ weeks of age. There were no significant differences on performance index among PL, Bio-Sel-E and commercial broiler diet fed groups at $5^{\text {th }}$ weeks of age but significantly differed $(P<0.01)$ with control group.

Table 6. Feed conversion ratio of broilers under different dietary treatments

\begin{tabular}{lllll}
\hline $\begin{array}{l}\text { Age } \\
(w k)\end{array}$ & \multicolumn{4}{c}{ Dietary treatment (Mean \pm SE) } \\
\cline { 2 - 5 } & Control & $\begin{array}{l}\text { Plantain } \\
(0.5 \% \text { of the } \\
\text { diet })\end{array}$ & Bio- Sel-E & $\begin{array}{l}\text { Commer-cial } \\
\text { diet }\end{array}$ \\
\hline $1^{\text {st }}$ & $1.39 \pm 0.01$ & $1.30 \pm 0.04$ & $1.33 \pm 0.01$ & $1.29 \pm 0.02$ \\
$2^{\text {nd }}$ & $1.50 \pm 0.05$ & $1.44 \pm 0.03$ & $1.48 \pm 0.01$ & $1.42 \pm 0.02$ \\
$3^{\text {rd }}$ & $1.73 \pm 0.03$ & $1.61 \pm 0.07$ & $1.65 \pm 0.03$ & $1.61 \pm 0.07$ \\
$4^{\text {th }}$ & $2.10^{\mathrm{a}} \pm 0.02$ & $1.91^{\mathrm{b}} \pm 0.04$ & $1.95^{\mathrm{b}} \pm 0.04$ & $1.93^{\mathrm{b}} \pm 0.05$ \\
$5^{\text {th }}$ & $2.31^{\mathrm{a}} \pm 0.03$ & $2.03^{\mathrm{b}} \pm 0.03$ & $2.11^{\mathrm{b}} \pm 0.03$ & $2.12^{\mathrm{b}} \pm 0.09$ \\
\hline
\end{tabular}

Mean values with dissimilar superscripts are in the same row differed significantly $(P<0.05)$; SE, standard error; NS, Non-significant $(P>0.05)$
Dressed yield (without skin) per cent of broilers are presented in Table 8. PL and commercial broiler diet fed groups showed significantly similar dressed yield (\%) which was lowest on control group. Table 4.5 represented insignificant differences among different treatment groups in terms of blood, shank, head, giblet and viscera weight (\%).

Overall mortality was $1.25 \%$ which is lower than accepted limit of commercial broiler. Only one bird from control and one from Bio-Sel-E group died during the whole experimental period and no treatment related adverse effect was detected.

Table 7. Performance Index (\%) of broilers under different dietary treatments

\begin{tabular}{lllll}
\hline $\begin{array}{l}\text { Age } \\
(\text { wk })\end{array}$ & \multicolumn{4}{c}{ Dietary treatment (Mean \pm SE) } \\
\cline { 2 - 5 } & Control & $\begin{array}{l}\text { Plantain } \\
(0.5 \% \text { of the } \\
\end{array}$ & Bio- Sel-E & $\begin{array}{l}\text { Commer-cial } \\
\text { diet }\end{array}$ \\
\hline $1^{\text {st }}$ & $9.2^{\text {}} \pm 0.02$ & $9.9 \pm 0.36$ & $9.8 \pm 0.30$ & $10.0 \pm 0.09$ \\
$2^{\text {nd }}$ & $16.2^{c} \pm 0.43$ & $23.0^{\mathrm{a}} \pm 0.58$ & $20.2^{\mathrm{b}} \pm 0.50$ & $23.3^{\mathrm{a}} \pm 0.48$ \\
$3^{\text {rd }}$ & $24.5^{\mathrm{c}} \pm 0.41$ & $34.9^{\mathrm{a}} \pm 1.45$ & $30.6^{\mathrm{b}} \pm 0.83$ & $35.0^{\mathrm{a}} \pm 1.35$ \\
$4^{\text {th }}$ & $30.6^{\mathrm{c}} \pm 0.42$ & $42.4^{\mathrm{a}} \pm 1.11$ & $38.3^{\mathrm{b}} \pm 1.05$ & $42.0^{\mathrm{a}} \pm 1.23$ \\
$5^{\text {th }}$ & $40.6^{\mathrm{b}} \pm 0.47$ & $56.0^{\mathrm{a}} \pm 1.17$ & $52.3^{\mathrm{a}} \pm 0.97$ & $54.0^{\mathrm{a}} \pm 3.27$ \\
\hline
\end{tabular}

Mean values with dissimilar superscripts are in the same row differed significantly $(p<0.01)$; SE, standard error 


\section{Broiler performance using Plantain, Bio-Sel- E and commercial diet}

Table 8. Carcass characteristics (\% live weight) of broilers under different dietary treatments at 35 days of age

\begin{tabular}{|c|c|c|c|c|c|}
\hline \multirow[t]{2}{*}{ Parameter } & \multicolumn{4}{|c|}{ Dietary treatment (Mean $\pm \mathrm{SE}$ ) } & \multirow{2}{*}{$\begin{array}{l}\text { Sig. } \\
\text { level }\end{array}$} \\
\hline & Control & $\begin{array}{l}\text { Plantain }(0.5 \% \\
\text { of the diet })\end{array}$ & Bio- Sel-E & $\begin{array}{l}\text { Commercial diet } \\
\text { (Quality Feed Ltd.) }\end{array}$ & \\
\hline Live weight (g) & $939^{b} \pm 6.88$ & $1136^{\mathrm{a}} \pm 18.52$ & $1105^{\mathrm{a}} \pm 20.71$ & $1138^{\mathrm{a}} \pm 19.16$ & $* *$ \\
\hline Blood (\%) & $6.1 \pm 0.52$ & $4.9 \pm 0.38$ & $5.1 \pm 0.45$ & $4.9 \pm 0.30$ & NS \\
\hline Shank (\%) & $4.7 \pm 0.09$ & $4.7 \pm 0.07$ & $4.1 \pm 0.26$ & $4.3 \pm 0.24$ & NS \\
\hline Head (\%) & $2.9 \pm 0.12$ & $2.8 \pm 0.38$ & $2.8 \pm 0.30$ & $2.9 \pm 0.29$ & NS \\
\hline Giblet (\%) & $7.7 \pm 0.58$ & $6.8 \pm 0.88$ & $7.3 \pm 0.87$ & $6.9 \pm 0.42$ & NS \\
\hline Skin (\%) & $15.3 \pm 0.97$ & $15.6 \pm 0.77$ & $15.2 \pm 0.85$ & $15.8 \pm 1.23$ & NS \\
\hline Viscera $(\%)$ & $11.3 \pm 1.57$ & $8.6 \pm 0.58$ & $8.6 \pm 0.92$ & $8.8 \pm 0.89$ & NS \\
\hline Dressed yield (\%) & $59.9^{b} \pm 2.16$ & $68.9^{a} \pm 3.08$ & $60.1^{b} \pm 2.62$ & $67.4^{a} \pm 2.35$ & $*$ \\
\hline
\end{tabular}

Mean values with dissimilar superscripts are in the same row differed significantly; SE, standard error; *, $\mathrm{P}<0.05 ; * *, \mathrm{P}<0.01 ; \mathrm{NS}$, Non-significant $(\mathrm{P}>0.05)$

\section{Discussion}

The result obtained in the present study revealed that, it is possible to get significant improvement of broiler performance by using PL, Bio-Sel-E and commercial broiler diet as compared to control during different stages of growth. Al-Mamun et al. (2008) observed that, plantain increased body protein synthesis in sheep exposed to heat; our experiment was performed in temperature around $30^{\circ} \mathrm{C}$ and found the increased body weight of broiler than control group which is similar with Al-Mamun et al. (2008). It was also reported that, poor lamb growth on the PL cultivar 'Grasslands Lancelot' (Fraser \& Rowarth, 1996) which is contradictory with this result. This contradictory result may be due the differences in the percentage of PL supplements.

Although at $5^{\text {th }}$ weeks of age PL, Bio-Sel-E and commercial broiler diet given insignificant body weight gain but significant than control group. Rumball et al. (1997) reported that, the growth rates of calves and lambs grazing mixed swards containing plantain has been good or enhanced which is agree with the current findings. Thomas et al. (1956) also found that, animal live weight gains have been improved by the inclusion of $\mathrm{PL}$ in the diet. Moorhead et al. (2002) was found that live weight gain was higher for lambs grazing PL than ryegrass swards when both were offered at an allowance diet. On the present study in case of broiler similar result was found. Those results are also in agreement with the current findings.

Kumar (1991) observed that, herbal formulations as growth promoters have shown encouraging results on feed intake in poultry birds. But the current research showed that there were no significant differences in feed intake of birds by supplementation of PL. It was observed that, in mixed pastures PL is highly palatable to cattle, sheep, deer and horses, and selectively grazed ahead of most legumes and grasses (Bhadresa et al., 1987) but in this study it was observed that, in case of broiler at $2^{\text {nd }}$ and $3^{\text {rd }}$ weeks the feed intake of PL group was significantly higher than control group but at $5^{\text {th }}$ weeks feed intake was insignificant of all groups. It may be due to the supplementation of lower dose of PL (0.5\%).

Chakravarty and Prasad (1991) achieved highest body weight gain and best feed conversion ratio as compared to control when offered neem leaf extract to broilers from 1 to 6 weeks. As like neem leaf in the current study PL given significantly higher FCR at $4^{\text {th }}$ and $5^{\text {th }}$ weeks than control group. Ghazalah and Ali (2008) investigated that, chicks fed rosemary leaves meal exhibited higher body weights, greater weight gain, and better feed conversion. PL also given the similar result like rosemary leaves meal in case of broiler.

Addition of $0.5 \% \mathrm{PL}$ given significantly higher performance index than control group but gives insignificant result with Bio-Sel-E and commercial 
broiler diet group. Hassan et al. (2004) observed that, herbal plants as growth promoters in broiler diets given a pronounced improvement in their body weight gain, feed conversion and performance index than control. PL also a natural antioxidant and given higher performance index in broiler that is similar with Hassan et al. (2004).

In this experiment, PL and commercial broiler diet fed group showed significantly similar dressing yield that differed from control group. Mohammad et al. (2011) found that, dietary supplementation of $1 \%$ Oregano, $0.5 \%$ Ziziphora and $0.5 \%$ Peppermint as a suggested medicinal mixture could improve broiler performance and carcass quality via more weight gain, increase carcass yield and decrease abdominal fat deposition. Dorfler and Roselt (1989) reported that, PL contain tannins, thus, too, might affect carcass composition but in this study some carcass characteristics showed insignificant result that is contradictory with it.

\section{Conclusion}

It may be concluded that feed conversion ratio of PL, Bio-Sel-E and commercial broiler diet groups were significantly $(p<0.05)$ lower than control.Performance index (\%) of PL, Bio-Sel$\mathrm{E}$ and commercial broiler diet groups were also significantly $(p<0.01)$ higher than control group. Supplementation of PL and Bio-Sel-E improve growth performance, feed conversion ratio and dressing yield of broilers. The performances almost similar with commercial broiler diet group. So, it is recommended to use $0.5 \%$ of Plantain and Bio-Sel-E $(5 \mathrm{~g} / 50$ birds with water) as supplement in modern poultry production. Further study may be done by increasing doses of Plantain and Bio-Sel-E.

\section{References}

Ahmad S (2005). Comparative efficiency of garlic, turmeric and kalongi as growth promoter in broiler. M.Sc. Thesis, Department of Poultry Science. University of Agriculture, Faisalabad, Pakistan.

Al-Mamun M, Hanai Y, Tanaka C, Tamura Y, Sano $H$ (2008). Responses of whole body protein synthesis and degradation to plantain herb in sheep exposed to heat. International J ournal of Biological Science, 3: 349-355.

Aritajat S, Saenphet K, Thaworn V, Wutteraphol S (2008). Effects of selected herbal extracts on blood profiles on rats. South. Asian Journal of Tropical Medicine and Public Health, 9: 78-81.

Bhadresa R. 1987. Rabbit grazing. Studies in a grassland community using faecal analysis and exclosures. Field studies, 6: 657-684.

Buckley DJ, Morrissey PA (1992). Animal production highlights. In: Vitamin $\mathrm{E}$ and Meat Quality, Hoffmann-La Roche Limited, Basel, Switzerland, P. 24-27.

Chakravarty A, Prasad J (1991). Study on the effect of Neem leaf extract and Neem cake extract on the performance of broiler chicks. Indian Journal of Poultry Science, 24(9): 37-38.

Deaker JM, Young MJ, Fraser TJ, Rowarth JS (1994). Carcass, liver, and kidney characteristics of lambs grazing plantain (Plantago lanceolata), chiocory (Cichorium intybus), white clover (Trifolium repens), or perennial ryegrass (Lolium perenne), Proceedings of the New Zealand Society of Animal Production, 54: 197-200.

Dorfler H, Roselt G (1989). The dictionary of healing plants. London, New York and Sydney, Blandford Press, P. 328.

Flachowsky G. 2002. Eggs and poultry meat as tocopherol sources in dependence on tocopherol supplementation of poultry diets. International Journal of Food Microbiology, 35: 239-243.

Fraser TJ, Rowarth JS (1996). Legumes, herbs or grass for animal performance, Proceedings of the New Zealand Grassland Conference, 58.

Ghazalah AA, Ali AM (2008). Rosemary leaves as a dietary supplement for growth in broiler chickens. International Journal of Poultry Science, 7: 234-239

Hassan I, Askar A, El-Shourbagy GA (2004). Influence of some medicinal plants on performance, physiological and meat quality traits of broiler chicks. Egyptian J ournal of Poultry Science, 24: 247-266.

Ihsan K (2003). Effect of different levels of kalongi ( $N$. sativa) seeds on the performance of broilers. M. Sc. Thesis, 


\section{Broiler performance using Plantain, Bio-Sel- E and commercial diet}

Department of Poultry Science. University of Agriculture, Faisalabad, Pakistan.

Kumar OM (1991). Effect of Liv-52 ${ }^{\circledR}$ syrup on broiler performance in North Eastern region. Indian Journal of Poultry Science, 22: $37-38$

Lanson RK, Smyth JR (1955). Pellets vs mash plus pellets vs mash for broiler feeding. Poultry Science, 34: 234-235

Lu J, Jang C. (2005). Selenium and cancer chemoprevention: hypotheses integrating the action of selenoproteins and selenium metabolites in epithelial and non-epithelial target cells. Journal of Medicine, 7: 17151727.

Marchesan M, Paper DH, Hose S, Franz G (1998). Investigation of the anti-inflammatory activity of liquid extracts of Plantago lanceolata L. Phycological Research 12: S33-S34.

Moorhead AJ E, Judson HG, Stewart AV (2002). Live weight gain of lambs grazing 'Ceres Tonic' plantain (Plantago lanceolata) or perennial ryegrass (Lolium perenne). Proceedings of the New Zealand Society of Animal Production, 62: 171-173.

Nishibe S, Murai M (1995). Bioactive components of Plantago herb. Foods and Food Ingredients Journal, 166: 43-49.

Ricke SC (2003). Perspectives on the use of organic acids and short chain fatty acids as antimicrobials. Poultry Science, 82: 632639.

Rumball W, Keogh RG, Lane GE, Miller JE, Claydon RB (1997). Grasslands Lancelot plantain (Plantago lanceolata). New
Zealand Journal of Agricultural Research, 40: 373-377.

SAS (1996). Statistical Analysis System/STAT ${ }^{\circledR}$ Software, Changes and Enhancements through Release 6.11. SAS Institute Inc., Cary, NC, USA.

Su L, Yin JJ, Charles D, Zhou K, Moore J, Yu L (2007). Total phenol contents, chelating capacities, and radical-scavenging properties of black peppercorn, nutmeg, rosehip, cinnamon and oregano leaf. Food Chemistry, 100: 990-997.

Thomas B, Rogerson A, Armstrong RH (1956). The influence of mineral-rich herbs on the yield and nutritive value of swards. Dry matter production and composition under pasture condition. Journal of the British Grassland Society, 11: 10-15.

Wang P, Kang J, Zheng R, Yang Z, Lu J, Gao J, Jia $Z$ (1996). Scavenging effects of phenylpropanoid glycosides from pedicularis on superoxide anion and hydroxyl radical by the spin trapping method. Biochemical Pharmacology, 51: 687-691.

Wegener HC, Aarestrup FM, Jensen LB, Hammerun AM, Bager $F$ (1999). Use of antimicrobial growth promoters in food animals and Enterococcus faecium resistance to therapeutic antimicrobial drugs in Europe. Emerging Infectious Diseases, 5: 329-335.

Whitracre ME, Combs GF, Combs SB, Parker RS (1986). Influence of dietary Vitamin $E$ on nutritional pancreatic atrophy in seleniumdeficient chicks. Journal of Nutrition, 117 460-467. 